\title{
KRYTYCZNE KOMPENDIUM TEONIMII SLOWIAŃSKIEJ W UJĘCIU FUNKCJONALNYM
}

(Michał Łuczyński „Bogowie dawnych Słowian. Studium onomastyczne”. KTN, Kielce 2020, 348 s.)

\section{Oleg LESZCZAK}

\author{
doktor habilitowany \\ profesor Uniwersytetu Jana Kochanowskiego w Kielcach, Polska \\ oleg.leszczak@ujk.edu.pl \\ https://orcid.org/0000-0003-3358-8923
}

DOI 10.25128/2304-1222.20.51.12

\begin{abstract}
The article is a review of a new monograph by Polish researcher Michał Łuczyński, devoted to the historical analysis of Slavic theonimic nominations. The article evaluates the innovative method of functional historical analysis of theonims.
\end{abstract}

Keywords: Michał Łuczyński, monograph, theonims, functional historical analysis.

Стаття становить огляд нової монографії польського дослідника Міхала Лучинського, присвяченої історичному аналізу слов'янських теонімічних номінацій. У статті оцінено інноваційний метод історичного функціонального аналізу теонімів.

Ключові слова: Міхал Лучинський, монографія, теоніми, функціональний історичний аналіз.

Artykuł stanowi recenzję nowej monografii polskiego badacza Michała Łuczyńskiego, poświęconej historycznej analizie teonimii słowiańskiej. W artykule została poddana ocenie zaproponowana przez autora monografii metoda funkcjonalnej analizy historycznej.

Słowa kluczowe: Michał Łuczyński, monografia, teonimy, funkcjonalnf analizf historyczna.

Książka dra Michała Łuczyńskiego powstała jako pokłosie jego doktoratu i dotyczy badań w niestety dość zmarginalizowanej w dzisiejszych czasach dziedzinie - lingwistyce historycznej, a precyzyjniej - badań w zakresie teonimii słowiańskiej. Wydawałoby się, co jeszcze można dodać do tego ogromu prac, które zostały temu tematowi poświęcono? Jak się okazało, można. Innowacje naukowe mają z reguły dwa źródła: ekstensywne lub intensywne. Albo naukowiec odrywa nowe fakty, albo szuka nowych sposobów opisu i objaśniania faktów starych. Autor niniejszej rozprawy wybiera drugą drogę, co nie powinno dziwić, biorąc pod uwagę raczej zamknięta listę badanych jednostek.

Monografia składa się z trzech części - teoretycznego wstępu, części materiałowej i części analitycznej. Warto podkreślić, iż wstęp teoretyczny ma, moim zdaniem, dość dużą wartość metodologiczną, ponieważ zawiera systemowy ogląd nie tyle dotychczasowych osiągnięć w dziedzinie mitologicznej antroponimii (a mianowicie teonimii i demononimii) Słowian, ile krytyczną analizę metodologii badań i podejść wykazującą niezmierną złożoność omawianej problematyki. Nie od dziś wiadomo, że badania historyczno-językowe, zwłaszcza dotyczące tak odległego okresu, jakim 
jest okres prabałtosłowiański bądź praindoeuropejski, bez należycie opracowanej metodologii są mało wiarygodne. Opracowania założeń metodologicznych wymagają nie tylko tradycyjne już kwestie rekonstrukcji fonetyczno-gramatycznych, lecz w o wiele szerszym zakresie zagadnienia rekonstrukcji semantyki i pragmatyki badanych faktów lingwalnych. Od czasów F. de Saussure’a jest znane, że istotą faktów lingwalnych jako funkcjonalnych bytów semiologicznych jest ich znaczącość (valeur), czyli wartość wewnętrzna (więź formy i sensu) oraz zewnętrzna (więzi jednostki z innymi jednostkami w systemie językowym i w wypowiedzi oraz podstawowa więź jednostki z oznaczanym przez nią pojęciem). To wszystko bardzo trudno dostrzec, jeśli chodzi o jednostki prasłowiańskie czy nawet późniejsze, których sens i wartość semiologiczna nie mogą być wystarczająco pełnie zweryfikowane. Przypomnę, że szwajcarski lingwista wyróżniał dwa rodzaje badań nad przeszłymi stanami systemu językowego - retrospektywny (polegający na opisie wyrwanych z systemu form) oraz historyczny (polegający na zestawieniu poszczególnych systemowych opisów kilku odrębnych stanów języka) [Saussure 2002: 21] $]^{4}$. Co się zaś tyczy systemowości, to zasadą podstawową w tej kwestii, czyli grand principe jest: „,ce qui est réel dans un état donné du langage, c'est ce dont les sujets parlants ont conscience, tout ce dont ils ont conscience et rien que ce dont ils peuvent avoit conscience" [tamże: 192] ${ }^{5}$. Posiadanie takiej świadomości językowej w przypadku faktów historycznych z góry jest niemożliwe, co czyni rozpowszechnioną w językoznawstwie historycznym metodę retrospektywną niemal całkowicie bezużyteczną, ponieważ ma ona sens tylko na tyle, na ile badacz „se justifie par le sentiment conforme de la langue” [tamże: 187] ${ }^{6}$. Analiza systemowa jest zaś zabiegiem dość skomplikowanym, ponieważ powinna być skonstruowana dedukcyjnie na zasadach scalenia systemowego wyłącznie przylegających do siebie faktów lingwalnych. „Przyleganie” owo powinno mieć wymiar nie tylko temporalny (odnosić się do tegoż funkcjonalnego okresu czasowego) i osobowy (odnosić się do w miarę jednolitego kolektywu językowego), ale także dyskursywny (dotyczyć tejże dyskursywnej odmiany języka). W przypadku badania mitologicznej antroponimii Słowian już sam zakres obiektu badawczego staje się mocno problemowy, gdyż chodzi o zbyt szeroki zakres czasowy, zbyt różnorodny zbiór osobowy i nie do końca jasny profil dyskursywny. Ten ostatni aspekt jest nie mniej ważny niż dwa pierwsze: wierzenia różnych grup plemion słowiańskich mogły mieć dość odmienny charakter ze względu chociażby na kulturowocywilizacyjny tryb ich życia. Michał Łuczyński sam zwraca uwagę na to, iż funkcje bogów u Słowian zachodnich w pewnym okresie miały charakter bardziej wojowniczy niż u Słowian wschodnich, co

\footnotetext{
${ }^{4}$ W odróżnieniu od „Kursu ogólnego językoznawstwa” w autentycznej pracy „De l'essence double du langage” Saussure wyróżnia nie dwa, a cztery typy badań językoznawczych: semiologiczny (= idiosynchroniczny, systemowy), diachroniczny (badanie fonetyczne wypowiedzi), retrospektywne (= etymologiczne) oraz historyczne. Systemową rewizję kluczowych postulatów de Saussure'a dokonała w swojej monografii ukraińska profesorka Oksana Prosianyk, zatem szczegółowe wyjaśnienie głównych różnic między tradycyjnym a „nowym” Saussure’em można znaleźć w jej rozprawie habilitacyjnej [Просяник 2018].

5 'rzeczą realną w tym stanie działalności językowej jest to, co uświadamiają użytkownicy języka, i tylko to, co oni uświadamiają'

6 'ma potwierdzenie w odczuciu językowym'
}

94 Studia methodologica, ISSN 2304-1222, No. 51. 2020 
świadczy właśnie o zróżnicowaniach kulturowo-cywilizacyjnych. Poza tym nie zawsze da się jednoznacznie odróżnić właściwe teonimy od poetyzmów i ideologemów (o czym Autor również wspomina w podrozdziale o funkcjonalnym zróżnicowaniu teonimów).

Moim zdaniem Autor recenzowanej monografii dość trafnie i w miarę wyczerpująco wypunktował w swoim wstępie teoretycznym podstawowe „zmory” historycznej onomastyki, zaczynając od problemowości ustalenia wiarygodności wielu form jednostek onimicznych (autentyczne, zdeformowane czy wręcz fałszywe), wiarygodności źródeł ich występowania (,pierwotne”, wtórne czy wręcz literackie), poprzez problemowość identyfikacji badanych jednostek pod względem denotacji (nazwy odrębnych obiektów mitycznych czy nazwy synonimiczne tegoż obiektu; hiponim czy hiperonim; derywat mutacyjny czy modyfikacja deminutywna) ${ }^{7}$ i wartości kulturowej (nazwa ogólnosłowiańska, arealna czy miejscowa), a także autentyczności ich etymologizacji (zapożyczenie czy słowo rodzime; słowo czy zbitka słów; który podział morfemowy jest poprawny, jaka jest semantyka morfemów i motywacja derywacyjna), aż do problemowości samego statusu badanego materiału (onim czy apelatyw; teonim, pseudo-teonim czy quasi-teonim). Zwraca Autor uwagę również na kwestie techniczne zgromadzenia materiału badawczego (błędy w zapisach, zniekształcenia przy kopiowaniu), a także na konieczność interdyscyplinarności tego rodzaju badań (załączenie analiz kulturoznawczych, religioznawczych, literackich, etnologicznych i stricte historycznych). 60-stronicowy wstęp teoretyczny zatem stanowi zwarte i treściwe zestawienie podstawowych koncepcji i teorii z zakresu teonimii słowiańskiej, w którym Autor nie boi się przeciwstawić starym i nowym, „rekinom” slawistyki historycznej, wykazując samodzielność myślenia, krytyczny umysł i dużą wiedzę. Ale także i pracowitość. Autor opracował około 800 prac naukowych z zakresu onomastyki historycznej oraz ponad 50 materiałów źródłowych i zrobił to naprawdę rzetelnie.

Istotne dla recenzowanej pracy jest to, że jest to rozprawa przede wszystkim źródłowoanalityczna, zatem trudno oczekiwać od Badacza rewolucyjnych propozycji metodologicznych o charakterze fundamentalnym. Niemniej jednak, już samo to, że Autor zdaje sobie sprawę z metodologicznych trudności podjętych badań i widzi swój problem badawczy systemowo i wielostronnie, wydaje się wystarczające dla w miarę pomyślnego rozwiązania postawionych przed sobą zadań. Dla mnie bardzo ważne było to, że Michał Łuczyński potrafi widzieć przeszłość językową przez pryzmat lingwosemiotyki funkcjonalnej, wyraźnie oddzielając kwestie formalne od semantycznych, a te ostatnie od aspektów pragmatycznych. Wielka to rzadkość wśród historyków języka. Poza tym na pochwałę zasługuję naukowa powściągliwość i tolerancja Autora. Kluczowymi

\footnotetext{
${ }^{7} \mathrm{~W}$ tym przypadku o wiele bardziej skomplikowany jest problem „tożsamości” bóstw. Jeśli w przypadku pojęć o rzeczach czy ich skupiskach można polegać na jakichś analogiach empirycznych, a w przypadku pojęć stricte abstrakcyjnych - na analogiach kognitywno-logicznych, to w przypadku pojęć o bytach mitycznych nie działa żadna z analogii. Mówiąc krócej, nawet w badaniach nad współczesnymi teologicznymi wyobrażeniami nie można mieć pewności, czy pojęcie Boga u chrześcijan, żydów i muzułmanów to jedno i to samo pojęcie, czy zupełnie odmienne pojęcia na siłę sprowadzane do jednego w celach utylitarnych lub politycznych. 
słowami rozprawy stały się „możliwy”, „wiarygodny”, „prawdopodobnie”, „być może”, „mogłoby”, „wydaje się”, „niewykluczone”. Mylne byłoby potraktowanie tego rodzaju znaczników jako autorskie widzimisię czy brak naukowości. Jest to jedynie dopuszczalna modalność wypowiadania się w badaniach tego typu.

Część materiałowa monografii (180 stron) jest zbudowana w postaci arealnego tezaurusa teonimów (głównie staroruskich, staropołabskich i staropolskich, w mniejszym stopniu staroczeskich, starołużyckich i starobułgarskich), którego każde hasło stanowi krytyczne zestawienie różnych etymologii i interpretacji semantyczno-pragmatycznych danej nazwy. Jest to swoiste kompendium wiedzy na temat teonimii słowiańskiej, w którym w sposób systemowy ujęte zostały podstawowe wiadomości na temat badań nad każdą nazwą (cały „słownik” zawiera 32 tego typu artykuły, chociaż czasem przedmiotem analizy w artykule staje się więcej niż jeden teonim).

Analiza własna Badacza pozwoliła mu na wysnucie wniosku, iż tylko $76 \%$ zbadanego materiału językowego to właściwe teonimy mitologiczne. Reszta to albo teonimy konfesyjne, albo apelatywy, które uległy quasi-onimizacji. W krótkiej części analitycznej, która pełni funkcję swoistych wniosków (ok. 30 stron), Autor przedstawia dane dotyczące polionimii w zakresie zbadanego nazewnictwa, specyfiki motywacyjno-derywacyjnej zbadanych form, temporalnego rozwarstwienia badanych teonimów, weryfikacji (a ściślej falsyfikacji) szeregu etymologicznych i interpretacyjnych hipotez, a także dokonuje podsumowań teoretycznych m.in. dotyczących magicznej funkcji teonimów dawnych Słowian jako najbardziej właściwej oraz demonstruje powiązania badań nad teonimią słowiańską i ogólnej etnokulturologii Słowian. Jednym z podstawowych wniosków, do których dochodzi Autor recenzowanej monografii jest to, że „prasłowiański system teonimiczny wyraźnie ciążył ku południowo- i wschodnioindoeuropejskim dialektom z doby różnicowania się języka pie. i jego powstanie można wiązać z okresem rozbicia dialektycznego obszaru ie.” [Łuczyński 2020: 289], „można tu mówić o prawdopodobnym wpływie substratów (lub adstratów) aryjskiego, scytyjskiego, wreszcie paleobałkańskiego na powstanie szeregu formacji teonimicznych” [tamże: 291] oraz (w kwestii przyczyn innowacji) „Na obecnym etapie wydaje się (...) iż musiały one zajść w dialekcie pie. (...) Dotychczas uważano na ogół, że część z nich uda się wywieść z domniemanych wpływów irańskich (okresu staroirańskiego) na prasłowiański język i kulturę duchową (w tym wierzenia, religię i mitologię), czego jednak nie potwierdzają wnioski zawarte w niniejszej pracy" [tamże].

Reasumując: książka Michała Łuczyńskiego jest bardzo interesującą, aczkolwiek nielekką „potrawą intelektualną” dla koneserów, ale także pożyteczną dla wszystkich tych, którzy są zainteresowani historią Słowian.

\section{LITERATURA}

Łuczyński, M. Bogowie dawnych Słowian. Studium onomastyczne. Kielce 2020.

Saussure F. de. Écrits de linguistique générale. Paris 2002.

Просяник, О. Фердинанд де Соссюр: деміфологізація концепції. Харків 2018 [Prosyanik, O. Ferdinand de Saussure: demifolohizatsiya kontseptsiyi. Kharkiv 2018]. 
STUDIA

METHODOLOGICA

No 51

Підписано до друку 25.12.2020 p.

Папір офсетний. 12,7 ум. др. ар.

Папір офсетний. Тираж 300.

Науково-редакційний відділ Тернопільського національного педагогічного університету імені Володимира Гнатюка 46027, Тернопіль, вул. М. Кривоноса, 2

Редакція наукового альманаху Studia methodologica Web: http://studiamethodologica.com. 